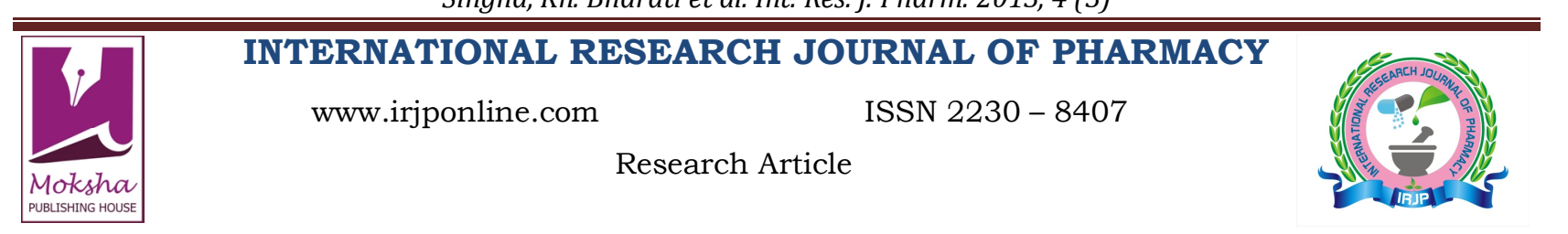

\title{
IN VITRO PROPAGATION OF DIPTERIS WALLICHII (R.BR.) T. MOORE: A HOPE FOR CONSERVATION OF AN ENDANGERED PTERIDOPHYTE
}

Singha, Kh. Bharati ${ }^{1}$, Dutta Choudhury, Manabendra ${ }^{1}$ and Mazumder, Pranab Behari ${ }^{2}$

${ }^{1}$ Plant Tissue Culture Laboratory, Department of Life Science and Bioinformatics, Assam University, Silchar 788011, India

${ }^{2}$ Department of Biotechnology, Assam University, Silchar 788011, India

Email: bembharati@yahoo.co.in

Article Received on: 13/01/13 Revised on: 09/02/13 Approved for publication: 11/03/13

DOI: $10.7897 / 2230-8407.04346$

IRJP is an official publication of Moksha Publishing House. Website: www.mokshaph.com

(C) All rights reserved.

\section{ABSTRACT}

The pteridophytes include the fern and fern allies which jointly create the necessary environment for human life on earth with other green plants. Dipteris wallichii (R.Br.) T. Moore is a rare and endemic pteridophyte of North East India. It is also facing severe threats due to its habitat destruction. Tribals destroy the plant in large numbers for preparing their wine drinking pipes. An in vitro protocol for micropropagation of D.wallichii Moore was carried out using standard Murashige and Skoog medium for spore germination and further cell proliferation. It was observed that supplementation of phytohormones mainly auxins (Indole-3-Acetic Acid) were favourable for sporophyte development from prothallus. Further growth and differentiation of the prothallus and sporophyte were recorded for various hormone concentrations and combinations and was observed to be best in $0.15 \mathrm{mg} / \mathrm{L} \mathrm{IAA}+0.20 \mathrm{mg} / \mathrm{L} \mathrm{KIN}$.

Key words: Dipteris wallichii, gametophyte, in vitro, phytohormones, sporophyte.

\section{INTRODUCTION}

In vitro propagation or micropropagation has led to two thrust areas of biotechnological applicationmicropropagation of elite plants and production of plant metabolites. It is estimated that there is a world market potential of 15 billion US \$ per annum for tissue culture products $^{1}$. Micropropagation is of specific importance in conservation of depletion and valuable genotypes of medicinal plants ${ }^{2}$.

The pteridophytes are the vascular plants that produce spores rather than seeds. Most of the ferns grow as thick ground cover and hence provide a good means to prevent soil erosion and they invade easily into exposed areas. Pteridophytes by virtue of their possessing great variety and fascinating foliage have drawn the attention and admiration of horticulturists and plant lovers for centuries. They are represented by about 305 genera, comprising more than 10,000 species all over the world. About 191 genera and more than 1000 species are reported from India. Medicinal value of pteridophytes is known to man for more than 2000 years. Again, the North East India has a rich vegetation of pteridophytes ${ }^{3,4,5,6}$. It is worth mentioning that the southern part of Assam (i.e. Barak valley) also has a rich vegetation of ferns and fern-allies.

The rare and economically important pteridophyte species should be treated as our natural heritage and properly conserved by ex situ conservation for the endemic and rare pteridophytes species by collecting live specimens from the wild and grow them in pots for propagation in Fernery ${ }^{7}$.

Ferns have worldwide distribution growing in all continents except Antarctica and most islands favouring moist temperate and tropical regions ${ }^{8}$. Ferns have been cultured in vitro to study their growth, development or differentiation and to achieve their micropropagation due to their ornamental value. Several species of ferns have successfully been propagated by this method ${ }^{9}$. Application of in vitro culture methods could contribute to increase sporophyte production of those desirable species. At the present time, a high number of individual researches are oriented towards the propagation of pteridophytes with a view to conserve their diversity.
The culture of tissue in ferns has been utilized as research instrument for the study of the developing potentialities of the leaf primordia ever since the early 1960 's ${ }^{10}$. The first successes in the field of the intensive multiplication of plants through in vitro techniques are cited around 1970, the fern Nephrolepis exaltata bostoniensis being the first plant micropropagated in vitro with a commercial purpose ${ }^{11} .157$ million plants, i.e. $74 \%$ out of the total production of micropropagated plants, have been ornamental species ${ }^{12}$. Out of these, approximately 40 million plants have been pot plants. Top of the list, with 17.8 million plants, is the fern Nephrolepis ${ }^{13}$.

Dipteris wallichii (R. Br.) T. Moore belongs to the family Dipteridaceae. The Dipteridaceae are a rather primitive group of ferns related to the Gleicheniaceae and distant from the Polypodiaceae, with the fossil record beginning in the Upper Triassic. Dipteris is the only living genus of the family Dipteridaceae while other genera, viz., Clatopteris, Dictyophyllum and Camptopteris are now extinct ${ }^{14}$. There are twelve species in the genus Dipteris and only two in IndiaDipteris wallichii (R. Br. ex Hook et Grev) T. Moore ${ }^{15,16}$ and Dipteris conjugata Reinw ${ }^{17}$. The species D.wallichii was first reported from Assam in Luckipoor ${ }^{18,19}$. Many works on the systematic and distribution pattern of D.wallichii was accomplished time to time with a mention of its distribution from Barak valley in Assam ${ }^{14}$. D. wallichii is an endemic fern to North Eastern region of Himalayas facing severe threats due to its habitat destruction and has been categorized under vulnerable category of the IUCN (2000). It survives in extremely specialized habitat near the streams in small isolated patches and is very distinct with its large, beautiful bi-lobed fronds. The decoction of its rhizome is taken to cure jaundice. Tribals destroy this plant in large numbers for preparing their wine drinking pipes.

In spite of its critical status, no attempts for in vitro conservation of the plant have been taken till date except the studies on the spore germination, developmental pattern and sexuality of gametophytes ${ }^{20}$. In the present paper, taking into consideration its sporadic occurrence in specialized habitats and its evolutionary importance, an attempt has been made to 
culture spores of D.wallichii Moore in vitro in order to save the plant from expected extinction. Therefore, in vitro culture and subsequent regeneration of sporophytes from the spore culture of the ferns will be very much helpful for mass cultivation as well as screening of phytochemicals present in the plant.

\section{MATERIALS AND METHODS}

Source of explant and sterilization: Mature sporophylls of D.wallichii Moore were collected from Baghbahar area of Cachar district, Southern Assam and were authenticated by the Department of Life Science and Bioinformatics, Assam University, Silchar. The spores were separated from air dried sporophylls and stored in a glass (reagent) bottle under refrigeration. Surface sterilization of spores was done with $35 \%(\mathrm{v} / \mathrm{v})$ solution of Sodium hypochlorite (4\% active chlorine) for 30 minutes before filtering through sterile (autoclaved) filter paper and washing several times with sterile double distilled water. The spores were then inoculated in nutrient medium with wet condition.

Preparation of culture medium: The nutrient medium used for inoculation of spores is Murashige and Skoog (MS) ${ }^{21}$ medium. The $\mathrm{pH}$ of the medium was adjusted to 5.8. After adjusting the $\mathrm{pH}$, agar powder $(0.8 \%)$ was mixed with the medium and boiled until a clear frothing solution was obtained and then poured in culture tubes and culture bottles respectively. Autoclave was done at $15 \mathrm{lbs} / \mathrm{sq}$. inch of pressure for 20 minutes to make the medium free of micro- organisms. The culture bottles and tubes containing the nutrient medium were then allowed to cool for 24 hours in the culture laboratory. The surface sterilized spores were inoculated in the culture tubes and bottles under Laminar Air Flow Cabinet to maintain the aseptic conditions. The cultured spores were incubated in Culture Room of the Tissue Culture Laboratory at $25^{\circ} \mathrm{C} \pm 1{ }^{\circ} \mathrm{C}$, under 16 hour photoperiod and 8 hour darkness.

\section{Morphological characters studied}

Prothallus structure, sporophyte length, fresh weight and dry weight of sporophyte developed from the same prothallus were studied. Germination percentage was also calculated from the following formula for each observation.

Germination percentage $(\%)=$

Total germinating spores in each miarogcopicfield Total spore X 100

\section{Effect of plant growth regulators}

Auxins [Indole-3-acetic acid (IAA)] and Cytokinin [Kinetin $(\mathrm{KIN})]$ were the different plant growth regulators (phytohormones) selected for study. Proportionate amount from stock solutions of different growth regulators were taken and the final volume of the medium was adjusted upto the mark in the volumetric flask. Different concentration and combinations of the growth regulators were tried and their effect on the growth of sporophytes studied.

Table 1: Average Germination Percentage

\begin{tabular}{|c|c|c|}
\hline Media no. & Media Composition & Germination percentage \\
\hline MS 1 & MS $+00 \mathrm{mg} / \mathrm{L}$ Sucrose $+0.0 \mathrm{mg} / \mathrm{L} \mathrm{IAA}$ & 11 \\
\hline MS 2 & MS $+00 \mathrm{mg} / \mathrm{L}$ Sucrose $+0.1 \mathrm{mg} / \mathrm{L} \mathrm{IAA}$ & 17 \\
\hline MS 3 & MS $+15 \mathrm{mg} / \mathrm{L}$ Sucrose $+0.1 \mathrm{mg} / \mathrm{L} \mathrm{IAA}$ & 12 \\
\hline MS 4 & MS $+15 \mathrm{mg} / \mathrm{L}$ Sucrose $+0.2 \mathrm{mg} / \mathrm{L} \mathrm{IAA}$ & 15 \\
\hline MS 5 & MS $+30 \mathrm{mg} / \mathrm{L}$ Sucrose $+0.1 \mathrm{mg} / \mathrm{L} \mathrm{IAA}$ & 10 \\
\hline MS 6 & MS $+30 \mathrm{mg} / \mathrm{L}$ Sucrose $+0.2 \mathrm{mg} / \mathrm{L} \mathrm{IAA}$ & \\
\hline
\end{tabular}

Table 2: Growth of Gametophytes (Prothalli) in fresh weight after 3 Months $(\mathbf{N}=10)$

\begin{tabular}{|c|c|c|}
\hline Media no. & Media composition & Weight of prothallus (mg) \\
\hline MS 7 (Control) & MS $+0.00 \mathrm{mg} / \mathrm{L} \mathrm{IAA}$ & 70.25 \\
\hline MS 8 & MS $+0.10 \mathrm{mg} / \mathrm{L} \mathrm{IAA}$ & 62.38 \\
\hline MS 9 & MS $+0.15 \mathrm{mg} / \mathrm{L} \mathrm{IAA}$ & 80.75 \\
\hline MS 10 & MS $+0.20 \mathrm{mg} / \mathrm{L} \mathrm{IAA}$ & 55.49 \\
\hline MS 11 & MS $+0.25 \mathrm{mg} / \mathrm{L} \mathrm{IAA}$ & 50.82 \\
\hline MS 12 & MS $+0.30 \mathrm{mg} / \mathrm{L} \mathrm{IAA}$ & 48.67 \\
\hline
\end{tabular}

Table 3: Growth of Sporophytes in terms of fresh and dry weight after 6 months

\begin{tabular}{|c|c|c|c|c|}
\hline $\begin{array}{c}\text { Media } \\
\text { Number }\end{array}$ & $\begin{array}{c}\text { KIN } \\
(\mathrm{mg} / \mathrm{L})\end{array}$ & $\begin{array}{c}\text { IAA } \\
(\mathrm{mg} / \mathrm{L})\end{array}$ & $\begin{array}{c}\text { Fresh weight }(\mathrm{g}) \\
(\text { Mean } \pm \text { SE })\end{array}$ & $\begin{array}{c}\text { Dry weight (g) } \\
(\text { Mean } \pm \text { SE })\end{array}$ \\
\hline MS 13(C) & 0.00 & 0.00 & $0.998 \pm 0.20$ & $0.325 \pm 0.19$ \\
\hline MS 14 & 0.05 & 0.15 & $1.045 \pm 0.26$ & $0.279 \pm 0.16$ \\
\hline MS 15 & 0.10 & 0.15 & $1.925 \pm 0.21$ & $0.530 \pm 0.20$ \\
\hline MS 16 & 0.15 & 0.15 & $2.545 \pm 0.18$ & $0.980 \pm 0.27$ \\
\hline MS 17 & 0.20 & 0.15 & $3.125 \pm 0.11^{*}$ & $1.002 \pm 0.15^{*}$ \\
\hline MS 18 & 0.25 & 0.15 & $3.050 \pm 0.13$ & $0.925 \pm 0.24$ \\
\hline MS 19 & 0.30 & 0.15 & $2.970 \pm 0.14$ & $0.875 \pm 0.18$ \\
\hline
\end{tabular}

*indicates significant differences at $\mathrm{p}<0.05$. Each concentration consisted of mean value of 3 replications and each replication of 10 culture bottles or flasks.

Table 4: Length of the Sporophytes after 3, 6, 8, 10 and 12 months

\begin{tabular}{|c|c|c|}
\hline Media number & Months & Length of Sporophytes (cm) \\
\hline MS 17 & 3 & 2.5 \\
\hline MS 17 & 6 & 3.2 \\
\hline MS 17 & 8 & 6.5 \\
\hline MS 17 & 10 & 7.2 \\
\hline MS 17 & 12 & 7.0 \\
\hline
\end{tabular}




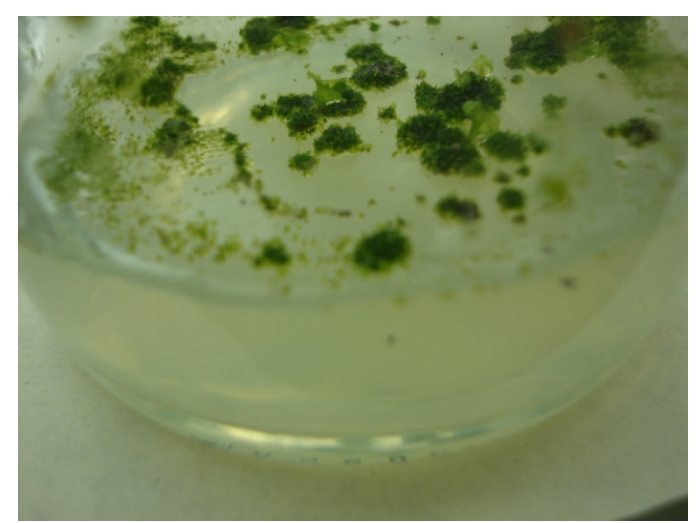

Figure1: Germinating spores and prothalli formation of D.wallichii Moore in vitro from spores

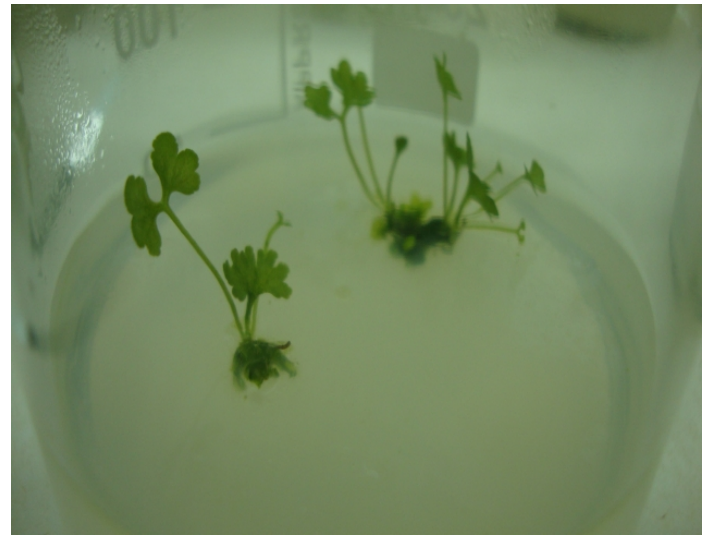

Figure 3: Developing sporophytes of D.wallichii Moore in MS 17 (4 months)

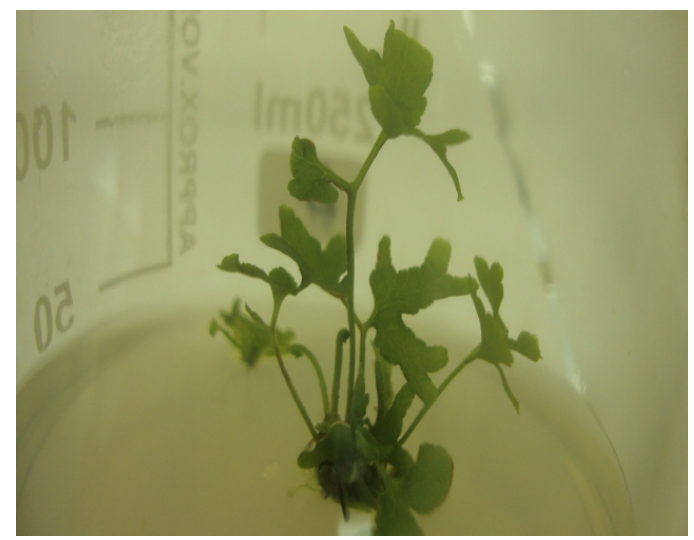

Figure 5: Sporophyte of D.wallichii Moore in MS 17 (8 month)

\section{RESULTS}

Germination of spores: Spores of D.wallichii Moore were found to germinate after 45 days from the day of inoculation. The germination percentage was found to be maximum $(50 \%)$ in the medium supplemented without sucrose and growth regulators (MS 1). Of all the germinated spores, sporophytic bodies did not develop. This may be due to short viability of the spores wherein delayed onset of ambient conditions compels spore degeneration in total and the admixed gametangia expression, where they compete for

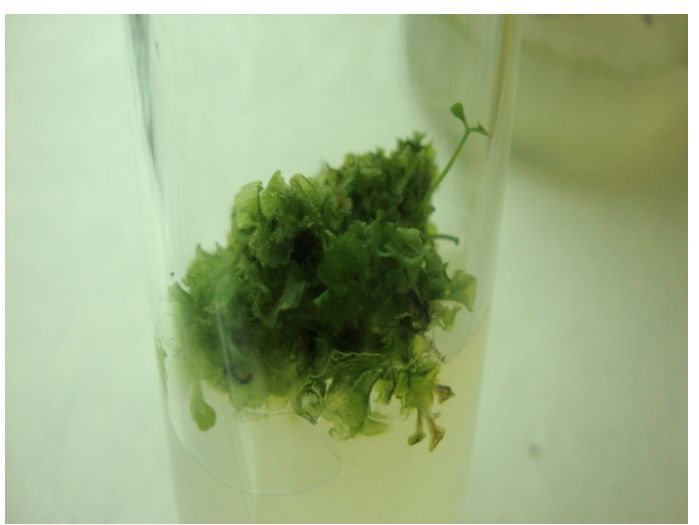

Figure 2: Multiplication and differentiation of prothallus of $D$. wallichii Moore to sporophytes in 3 months.

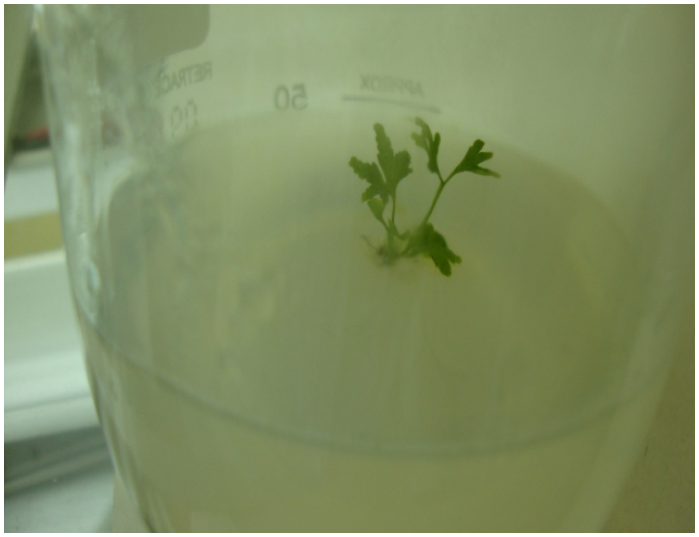

Figure 4: A 6 month old sporophyte of D.wallichii Moore in MS 17

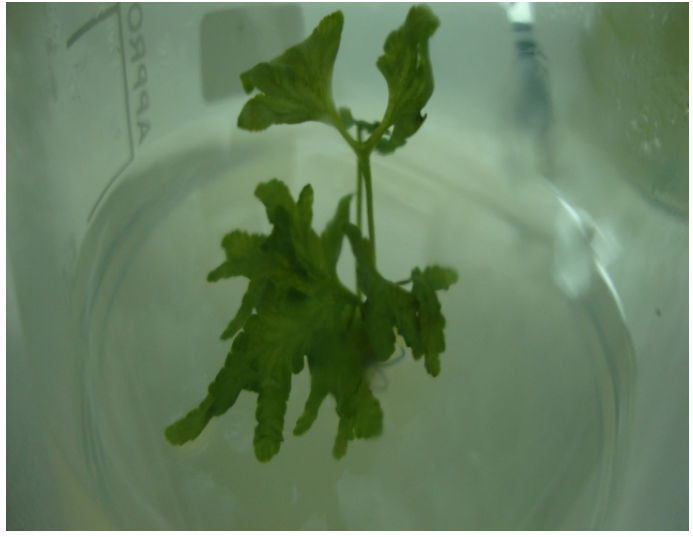

Figure 6: A fully grown sporophyte of D.wallichii Moore in MS 17 (10 month)

their nutritional demands, failing which the developing gametangia degenerate upto half of their numbers ${ }^{20}$.

Prothallus development: Spores germinate to produce prothallus. After germination, the spores divide into prothallial initial and rhizoidal initial. The prothallial initial produce prothallus and rhizoidal initial produce unicellular rhizoids. The prothallus is heart shaped structure and bears antheridia (male sex organs) and archegonia (female sex 
organs). The prothalli are long lived and become more or less elongated with age.

Effect of growth regulators on the development of gametophytes: Five concentrations of Indole-3-acetic acid (IAA) viz., $0.10 \mathrm{mg} / \mathrm{L}, 0.15 \mathrm{mg} / \mathrm{L}, 0.20 \mathrm{mg} / \mathrm{L}, 0.25 \mathrm{mg} / \mathrm{L}$ and $0.30 \mathrm{mg} / \mathrm{L}$ were selected for culture of prothallus in MS medium. The fresh weight (in $\mathrm{mg}$ ) of the prothallus were recorded after a period of 3 (three) months. It was observed that MS 9 gave the maximum average growth of the prothallus bearing gametophytes. Hence $0.15 \mathrm{mg} / \mathrm{L}$ of IAA was considered as the optimum dose of IAA for the culture of prothallus with different combination of growth regulators in MS medium.

Development of sporophyte: Young sporophytic bodies were found to develop from the prothallus (bearing both gametophytic structures). The antheridia produce spermatozoids and each archegonium produce one egg. The spermatozoids fertilize the egg to produce diploid sporophyte. Maximum growth of sporophytes was observed in MS 17 followed by MS 18 and MS 19. It was observed that increase in KIN concentration (keeping IAA concentration constant) result in increase of fresh and dry weight of the sporophytes ${ }^{22}$.

Development of root-like rhizoids: The young sporophytic bodies in the culture bottles were observed to develop rootlike rhizoids. The maximum increase of plant height was found to be $7.2 \mathrm{~cm}$ in MS 17. It may be due to maximum growth of root-like rhizoids.

Hardening: The fully grown sporophytes were carefully taken out from the culture bottles and washed gently with sterile double distilled water to remove adhering agar medium so that contamination does not occur. The regenerated sporophytes were transferred to vermiculite (a sterile inert medium) and hardened by covering them with a thin perforated transparent polythene bag to maintain humidity and sprayed with $1 / 10^{\text {th }}$ strength MS salts solution and maintained in the culture condition for acclimatization. Finally, the sporophytes were transplanted to earthen pots containing sterile dried moss, sand and brick bats in the ratio of $1: 1: 1$.

\section{DISCUSSION}

The main problem for establishment of in vitro propagation protocols in pteridophytes is the presence of micro-organisms in the plants, hindering the process of disinfection and affecting their survival ${ }^{23}$. Spores have been used as the explant source for successful high frequency regeneration of plants. Although the regeneration of plants from spores is quite difficult in vitro, but optimization of every step from initiation to acclimatization makes it more feasible to produce plants from spores in vitro ${ }^{24}$.

Sterilization of spores of D.wallichii Moore with $0.1 \%$ Mercuric chloride for 2 to 3 minutes results in very poor germination. But when treated with $35 \%(\mathrm{v} / \mathrm{v})$ Sodium hypochlorite solution (4\% active chlorine) for half an hour, better germination percentage was observed. Lowering the percentage of Sodium hypochlorite and time period leads to contamination by fungus and bacteria. So standardization of the explants sterilant and time period by trial and error method is essential for better germination. Harvested spores lose their viability if stored for more than 6 months and exhibit less germination percentage ${ }^{25}$. So it is better to use fresh spores for germination.

Fern spores grow in sugar deficient medium containing macro and micro nutrients and differentiate sex organs. When supplemented with sucrose, contamination occurs and growth regulators supplementation did not make much difference (Table No.1). It was reported that Dyer and MS medium supplemented with sucrose resulted in lower germination and early gametophyte development of endangered fern Dicksonia sellowiana ${ }^{25}$. High sucrose level in the culture medium might result in chlorophyll degradation and reflect on the frond development ${ }^{26}$. In vitro plant regeneration had been successful for Cyathea lepifera in half strength MS medium without sucrose ${ }^{27}$.

Germination percentage was found to be maximum (50\%) for spores of D.wallichii Moore in MS basal medium (MS 1). Of all the germinated spores, sporophytic bodies did not develop. This may be due to the fact that short viability of the spores compels spore degeneration in total and the developing admixed gametangia degenerate upto half of their numbers because of nutritional demands. Also rhizomatous propagation rather than spore germination (which is common among most ferns) occurs in D.wallichii Moore and hence localised in distribution.

After germination, all spores become green in colour and were transferred to MS medium supplemented with growth regulators. It was observed that MS medium supplemented with $0.15 \mathrm{mg} / \mathrm{L}$ IAA (MS 9) supported best growth of gametophytes in terms of fresh weight $(80.75 \mathrm{mg})$ as shown in Table No.2. Increasing concentration of IAA resulted in decline of the fresh weight of the gametophytes.

Sporophytes developed from gametophytes in three months. In order to study the combined action of IAA and KIN on the developing sporophytes, six combinations were taken. Out of which, $0.15 \mathrm{mg} / \mathrm{L} \mathrm{IAA}+0.20 \mathrm{mg} / \mathrm{L} \mathrm{KIN} \mathrm{(MS} \mathrm{17)} \mathrm{showed}$ better results in terms of fresh weight $(3.125 \mathrm{~g})$ of sporophytes (Table No.3). Growth increased manifolds due to combined action of IAA and KIN because auxins alone lead to cell enlargement while KIN induces cell division in presence of auxin ${ }^{28}$. Cytokinin is also helpful in lipid metabolism to increase growth ${ }^{29}$.

Height of sporophytes of D.wallichii Moore were measured in random. Maximum average height of the sporophytes (7.2 $\mathrm{cm}$ ) were observed in MS 17 i.e. $0.20 \mathrm{mg} / \mathrm{L} \mathrm{KIN}+0.15 \mathrm{mg} / \mathrm{L}$ IAA. After the complete sporophyte regeneration, hardening was done and the sporophytes were gradually exposed to the natural environment, where they exhibited $80 \%$ survivability. The present study describes the requirements for in vitro spore germination and gametophyte development of this highly endangered species - Dipteris wallichii Moore. The results may promote large scale cultivation to compensate its depletion in nature.

\section{REFERENCES}

1. Govil S, Gupta SC. Plant Micropropagation Industry in India: retrospect and prospect. J Scientific and Industrial Research 1994; 5(3):777-786.

2. Sen J, Sharma AK. Micropropagation of Withania somnifera from germinating seeds and shoot tips. Plant Cell Tissue and Organ Cult 1991; 26:71-73. http://dx.doi.org/10.1007/BF00036108

3. Kachroo P. Ferns of Assam. J Asiatic Soc Sci 1935; 19:161-174.

4. Baishya AK, Rao RR. Fern and Fern-allies of Meghalaya State, India, Scientific Publisher, Jodhpur; 1982.

5. Borthakur SK, Deka P, Nath RK. In: Singh B, Singh MP, Eds. Illustrated Manual of Ferns of Assam; 1999.

6. Singh S, Panigrahi G. In: Singh B, Singh MP, Eds. Ferns and fern-allies of Arunachal Pradesh, Dehradun; 2005.

7. Amoroso VB. Pteridophyte and gymnosperm diversity in Musuan, Bukidnon, Philippine. J Systematic Biol 2006; 1:1-11. 
8. Burkhill IH. A Dictionary of the Economic Products of Malay Peninsular, Ministry of Agriculture Malaysia; 1935. p.1542.

9. Hartman RD, Zettler FW. Tissue culture as a plant production system for foliage plants. In: Zimmerman RH, Griesback RJ, Hamnerschlag FA, Lawson RH, Eds. Tissue Culture as a Plant Production System for Horticultural Crops, Martinus Nijhof Publishers, Dordrecht; 1986. p. 293-299. http://dx.doi.org/10.1007/978-94-009-4444-2 25

10. Torres KC. Tissue Culture Techniques for Horticultural Crops. Van Nostrand Reinhold, New York; 1988. http://dx.doi.org/10.1007/978-14615-9756-8

11. Cachita-Cosma D. Metode in vitro la plantele de cultura-baze teoretice si practice, Edit. Ceres, Bucuresti; 1988. p. 274.

12. Pierik RML. Commercial aspects of micropropagation. In: Prakash J, Pierik, RML, Eds. Horticulture-New Technologies and Applications, Kluwer Academic Publishers, Dordrecht, the Netherlands; 1991. p. 141153. http://dx.doi.org/10.1007/978-94-011-3176-6 23

13. Fernandaz H, Revilla MA. In vitro culture of ornamental ferns. Plant Cell Tissue and Organ Cult 2003; 73:1-13. http://dx.doi.org/10.1023/ A: 1022650701341

14. Dutta Choudhury M, Das PS. Ecology and distribution pattern of Dipteris wallichii (R.Br.) Moore in Southern Assam, NE India. Indian Fern J 2005; 22:124-127.

15. Dixit RD. A Census of Indian Pteridophytes. Director Botanical Survey of India Howrah; 1984. PMCid:1153614

16. Fraser-Jenkins CR. In: Singh B, Singh MP, Eds. Taxonomic revision of three hundred Indian subcontinental Pteridophytes with a revised census-list. Dehradun, India; 2008.

17. Satija CK, Bir SS. Polypodiaceous ferns of India. In: Bir SS, Ed. Aspects of Plant Sciences. Today \& Tomorrow's Printers and Publishers, New Delhi; 1985. PMCid:3011173

18. Hooker JD, Thompson T. Flora Indica, London; 1855. http:// dx.doi.org/10.5962/bhl.title. 50109

19. Beddome RH. Handbook to the ferns of British India, Ceylon and Malaya Peninsula. Thacker Spinc. \& Co., Calcutta; 1883

20. Behera SK, Rawat VK, Singh AP, Khare PB. Spore germination, developmental pattern and sexuality of gametophytes in Dipteris wallichii (R. Br. ex Hook. et Grev) T. Moore. Indian Fern J 2011; 28(12):172-178

21. Murashige T, Skoog F. A revised medium for rapid growth and bioassays with tobacco tissue cultures. Physiologia Plantarum 1962; 15:473-497. http://dx.doi.org/10.1111/j.1399-3054.1962.tb08052.x

22. Mazumder B, Dutta Choudhury M, Mazumder PB. Effect of growth regulators on in vitro propagation of Bolbitis costata (Wall ex. Hook.) C. Chr., Assam University J Sci and Tech: Biol and Environ Sci 2010; 5:23-33.

23. Morini S. In vitro culture of Osmunda regalis fern. J Hortic Sci and Biotech 2000; 75:31-34.

24. Banks JA. Gametophyte development in Ferns. Annual Rev of Plant Physiol1999;50:163-186. http://dx.doi.org/10.1146/annurev.arplant. 50.1.163 PMid: 15012207

25. Renner GDR, Randi AM. Effects of sucrose and irradiance on germination and early gametophyte growth of the endangered tree fern Dicksonia sellowiana Hook (Dicksoniaceae). Acta Bot Bras 2004; 18:375-380. http://dx.doi.org/10.1590/S0102-33062004000200017

26. Fernandez H, Bertrand AM, Sanchez-Tames R. Biological and nutritional aspects involved in fern multiplication. Plant Cell Tissue and OrganCult1999;56:211-214.http://dx.doi.org/10.1023/A: 1006277229 $\underline{136}$

27. Kuriyama A. Kobayashi T. \& Maeda M. Production of sporophytic plants of Cyathea lepifera, a tree fern, from cultured gametophytes. J Jap Soc Hortic Sci 2004; 73:140-142. http://dx.doi.org/10.2503/jishs. 73.140

28. Steward FC, Shantz EM. The chemical induction of growth in plant tissue culture. In: Wren RL, Wightman F, Eds. The chemistry and mode of action of plant growth substances; 1955. p. 165-185.

29. Manning JC, Van Staden J. The development and mobilization of seed reserves in some African Orchids. Aust J Bot 1987; 35:343-353. http://dx.doi.org/10.1071/BT9870343

\section{Cite this article as:}

Singha, Kh. Bharati, Dutta Choudhury, Manabendra and Mazumder, Pranab Behari. In vitro propagation of Dipteris wallichii (R.Br.) T. Moore: A hope for conservation of an endangered pteridophyte. Int. Res. J. Pharm. 2013; $4(3): 215-219$ 